\title{
KETERSEDIAAN STANDAR DALAM MENDUKUNG PENERAPAN SISTEM SMART GRID DI INDONESIA
}

\section{Availability Standards in Supporting of the Application of Smart grid System in Indonesia}

\author{
Danar Agus Susanto dan Bendjamin B. Louhenapessy \\ Pusat Penelitian dan Pengembangan Standardisasi, Badan Standardisasi Nasional \\ Gedung Manggala Wanabakti Blok IV Lantai 4, Senayan, Jakarta, Indonesia \\ e-mail: danaragus46@gmail.com, bendjamin_1711@yahoo.co.id
}

Diterima: 14 Maret 2014, Direvisi: 19 Mei 2014, Disetujui: 9 Juni 2014

\begin{abstract}
Abstrak
Smart grid didefinisikan sebagai jaringan listrik cerdas yang dapat mengintegrasikan tindakan semua pengguna yang terhubung, seperti generator/pembangkit listrik, konsumen dan orang-orang yang melakukan keduanya dalam rangka untuk efisiensi dalam memberikan pasokan listrik yang berkelanjutan, ekonomis dan aman (IEC, 2010). Saat ini penerapan sistem smart grid sudah diuji coba di Indonesia melalui program pemerintah yaitu pilot projek sistem smart grid di Sumba Barat Daya, Nusa Tenggara Timur (NTT). Sistem ini sangat cocok dikembangkan di Indonesia dengan melihat kondisi geografis Indonesia yang terdiri dari sekitar 17.000 pulau besar dan kecil, di mana angka rasio elektrifikasi tahun 2012 sebesar 78\% dan kapasitas listrik 76,9\% berada dipulau jawa. Salah satu tantangan dalam penerapan sistem smart grid adalah terkait dengan standardisasi, smart grid tidak akan "smart" jika tidak didukung oleh sebuah kerangka kerja yang standar untuk komunikasi antara perangkat. Berkaitan dengan permasalahan tersebut, maka tujuan dalam penelitian ini adalah untuk mengidentifikasi ketersediaan standar dalam penerapan smart grid di Indonesia. Hasil penelitian ini yaitu teridentifikasi komponen dan standar (SNI, standar internasional dan standar manca negara) sistem smart grid yang terdiri dari sistem photovoltaic, sistem baterai, sistem kontrol dan Energy Management Systems (EMS), sistem komunikasi, sistem genset (biodisel) dan sistem micro hydro. Ketersediaan standar terkait dengan komponen sistem smart grid ini diharapkan dapat mendukung penerapan sistem smart grid di Indonesia.
\end{abstract}

Kata kunci: smart grid, standar, efisiensi penyaluran listrik.

\begin{abstract}
Smart grid is defined as electricity network that can intelligently integrate the actions of all users connected to it, such as a generators, consumers and those that do both, in order to efficiently deliver sustainable, economic and secure electricity supplies (IEC, 2010). The current implementation of the smart grid system has been tested in Indonesia through a government program is a pilot project of smart grid systems in Southwest Sumba island in Nusa Tenggara Timur (NTT). This system is very suitable to be developed in Indonesia with the geographic condition of Indonesia consists of 17,000 islands large and small, where the electrification ratio in 2012 of $78 \%$ and $76.9 \%$ of electricity capacity are on an island of Java. One of the challenges in implementing smart grid systems is related to standardization, the smart grid systems will not be "smart" if it is not supported by a framework of standards for communication between devices. In connection with these problems, the goal of this research is to identify the availability of standards in implementation of smart grid systems in Indonesia. The results of this research that identified the components and standards (ISO, the international standards and foreign standards ) smart grid system consisting of photovoltaic systems, battery systems, control systems and Energy Management Systems ( EMS ), communication systems, generator systems (biodiesel) and the system micro hydro. Availability of standards related to smart grid system components are expected to support the implementation of smart grid systems in Indonesia .
\end{abstract}

Keywords: smart grid, standard, efficiently deliver of electricity.

\section{PENDAHULUAN}

Kehidupan manusia tidak bisa dilepaskan dari pentingnya kebutuhan energi. Energi mengisi aktivitas apapun yang dilakukan manusia. Sampai saat ini salah satu jenis energi yang paling banyak digunakan oleh manusia adalah energi listrik. Mengingat pentingnya manfaat energi listrik bagi kehidupan manusia, sedangkan sumber energi pembangkit listrik terutama yang berasal dari sumber energi baru dan terbarukan keberadaannya terbatas, maka untuk menjaga kelestarian sumber energi ini perlu diupayakan langkah-langkah 
strategis yang dapat menunjang penyediaan energi listrik secara optimal dan terjangkau.

Saat ini ketersediaan sumber energi listrik tidak mampu memenuhi peningkatan kebutuhan listrik di Indonesia. Terjadinya pemutusan sementara dan pembagian energi listrik secara bergilir merupakan dampak dari terbatasnya energi listrik yang dapat disuplai oleh PT. Perusahaan Listrik Negara (PLN). Hal ini terjadi karena laju pertambahan sumber enegri baru dan pengadaan pembangkit tenaga listrik tidak sebanding dengan peningkatan konsumsi listrik (Alhanif, 2007).

Upaya menambah pembangkit sebenarnya telah banyak dilakukan, namun membutuhkan proses yang lama dan anggaran yang besar. Oleh karena itu, kerja sama dan partisipasi berbagai pihak sangat diperlukan untuk mengatasi krisis energi listrik ini. Berbagai upaya perlu dilakukan untuk mengatasi krisis energi listrik ini secara simultan dan terstruktur. Salah satu langkah strategis yang dapat dilakukan diantaranya perbaikan sistem distribusi listrik.

Saat ini sistem distribusi listrik yang digunakan oleh PLN umumnya adalah sistem sentralisasi listrik. Sistem tersebut ternyata dapat membawa dampak buruk dalam distribusi listrik di Indonesia. Diantaranya menyebabkan banyaknya wilayah yang sulit dicapai oleh jaringan listrik dan faktor geologisnya buruk, tidak dapat menikmati listrik. Selain itu, dapat juga menyebabkan terjadinya penyusutan tenaga listrik, tidak stabilnya tegangan listrik hingga pada pemadaman aliran listrik yang berakibat seluruh wilayah yang bergantung pada gardu tertentu akan mengalami black out (Alhanif, 2007).

Berdasarkan permasalahan tersebut, maka dibutuhkan suatu sistem pengelolaan energi terbarukan yang dapat menyokong penyediaan energi listrik saat ini. Suatu sistem pengelolaan energi terbarukan yang dapat menjangkau seluruh pelosok tanah air. Itulah sistem desentralisasi listrik, sistem ini menggunakan pembangkit listrik berskala kecil yang terdesentralisasi (tersebar) di seluruh daerah rawan listrik dan membutuhkan pasokan listrik yang besar. Saat ini alat untuk mendukung sistem desentralisasi listrik telah tersedia, misalnya turbin gas mikro, mikro hidro dan lain-lain.

Sistem desentralisasi tersebut, saat ini disebut sebagai sistem mikrogrid yang sangat gencar dikembangkan karena lebih memanfaatkan sumber-sumber energi alternatif lokal tanpa melupakan sumber energi konvensional. Namun suatu pemikiran yang lebih maju lagi tentang konsep penyaluran energi listrik sekarang sudah mulai berkembang juga di berbagai negara, konsep tersebut sering disebut smart grid. Sistem atau konsep smart grid ini merupakan konsep jaringan energi cerdas yang dicita-citakan untuk memenuhi kebutuhan energi listrik yang di masa sekarang maupun masa yang akan datang di mana energi menjadi kebutuhan primer bagi manusia.

Salah satu tantangan dalam penerapan sistem smart grid adalah terkait dengan standardisasi, smart grid tidak akan "smart" jika tidak didukung oleh sebuah kerangka kerja yang standar untuk komunikasi antara perangkat. Jika standar belum ditetapkan, tidak ada jaminan bagi teknologi smart grid agar dapat plug and play serta dapat memecahkan solusi untuk masalah yang kurang baik sepanjang jaringan tersebut. Disamping masalah tersebut, perusahaan dan vendor juga tidak akan mau berinvestasi untuk mengembangkan peralatan yang mahal dan tidak kompatibel pada sistem. Pembuatan aturan untuk standarisasi memiliki ruang lingkup yang sangat luas dan kompleks karena bergantung pada visi smart grid. Karena inilah stadarisasi menjadi subjek yang sangat penting di dalam mendukung operasionalisasi suatu sistem smart grid (Muqorobin, A, Dkk, 2011). Berkaitan dengan permasalahan tersebut, maka tujuan dalam penelitian ini mengidentifikasi ketersediaan atau kebutuhan standar dalam penerapan smart grid di Indonesia.

\section{TINJAUAN PUSTAKA}

\subsection{Sekilas Tentang Sistem Smart grid.}

Sebagai sebuah negara kepulauan, potensi untuk mengembangkan sumber energi kelistrikan berbasis smart grid di Indonesia cukup besar. Smart grid merupakan sistem ketenagalistrikan generasi baru yang dicirikan oleh meningkatnya penggunaan komunikasi dan teknologi informasi dalam pembangkitan, distribusi dan konsumsi energi listrik. Ini merupakan sumber energi kelistrikan dengan konsep terintegrasi dan mengurangi ketergantungan terhadap sumber daya alam yang tidak dapat diperbaharui.

Beberapa organisasi di dunia memberikan definisi yang sedikit berbeda mengenai smart grid. Menurut Department of Energy (DoE) US, smart grid adalah integrasi dari teknologi pembacaan (sensing), metode pengendalian, dan komunikasi pada sistem tenaga listrik yang sudah ada sekarang ini (Rizqiawan, 2009). Dalam IEC roadmap, smart 
grid di definisikan sebagai "electricity network that can intelligently integrate the actions of all users connected to it - generators, consumers and those that do both - in order to efficiently deliver sustainable, economic and secure electricity supplies" (IEC, 2010). Smart grid adalah konsep jaringan cerdas yang dicitacitakan untuk memenuhi kebutuhan energi listrik yang di masa sekarang maupun masa mendatang sudah menjadi kebutuhan primer. Dimana komunikasi terjadi dua arah antara produsen listrik serta konsumennya telah diimplementasikan menggunakan teknologi analog bertahun-tahun lamanya (Rizqiawan, 2009).

Menurut Dr. Praba Kundur, Smart grid adalah sebuah jaringan tenaga listrik yang secara cerdas mengintegrasikan tindakantindakan seluruh pengguna yang terhubung, seperti: generator, transmisi, dan pelanggan, yang secara efisien menghasilkan suplai tenaga listrik yang sustainable, economic, dan secure. Komponen pembentuk smart grid adalah infrastruktur ketenagalistrikan dan infrastruktur cerdas (teknologi informasi) yang terintegrasi dalam satu sistem yang kompak. Terintegrasinya kedua infrastruktur tersebut memastikan bahwa setiap keputusan yang diambil dan dieksekusi oleh infrastruktur tenaga listrik telah melalui proses analisa oleh kecerdasan buatan yang telah ditetapkan sebelumnya (Dr. Praba Kundur dalam Sutrisno, 2013 ).

Definisi yang lain mengenai smart grid yaitu power system yang memiliki lebih dari satu sistem transmisi dan distribusi otomatis dimana kesemuanya beroperasi dengan terkoordinir, efisien dan reliable. Power system yang memiliki infrastruktur komunikasi yang pintar, memberikan kemungkinan adanya flow informasi yang aman, adaptif dan cepat. Power system yang mampu mengatasi kondisi darurat karena dilengkapi denga fitur "self healing" serta responsif terhadap perubahan supply dan demand. Power system yang merupakan kumpulan berbagai teknologi untuk mengirimkan listrik secara fleksibel, mudah diakses, reliable serta ekonomis. Smart grid merupakan suatu sistem yang mampu untuk memfasilitasi kebutuhan penggunanya, mulai dari pengaturan distributed generation, manajemen kebutuhan, serta sistem energy storage (Happy Yolanda, 2013).

Dalam Standards Council of Canada dalam buku "The Canadian Smart grid Standards Roadmap", smart grid di definisikan sebagai penerapan teknologi dimana sektor telekomunikasi merupakan pioner utama untuk seluruh rantai pasokan listrik, yang memungkinkan komunikasi yang lebih baik secara real time dari generator ke transmisi dan distribusi, sampai ke meter listrik, dan bahkan di dalam jaringan pelanggan (Standards Council of Canada/SCC ,2012).

\subsection{Skema Dasar Sistem Smart grid.}

Teknologi smart grid seperti yang ditunjukkan pada Gambar 1 terdiri dari jaringan komunikasi, sensor canggih, dan peralatan pemantauan, yang mendasari konsep baru pembangkitan dan penyaluran daya. Smart grid memungkinkan adanya aliran daya dua arah, hal ini dikarenakan banyaknya pembangkitan yang terdistribusi terutama pada wilayah beban. Aliran daya ini perlu diatur agar didapatkan kinerja jaringan yang efisien dan optimal. Untuk mengatur aliran daya tersebut diperlukan pengaturan pada peralatan atau aset-aset yang berada pada jaringan, maka dari itu smart grid sangat erat kaitannya dengan teknologi komunikasi dan informasi. Pengaturan ini dapat dilakukan karena smart grid memiliki sistem komunikasi data dua arah (Muqorobin, A, Dkk, 2011).

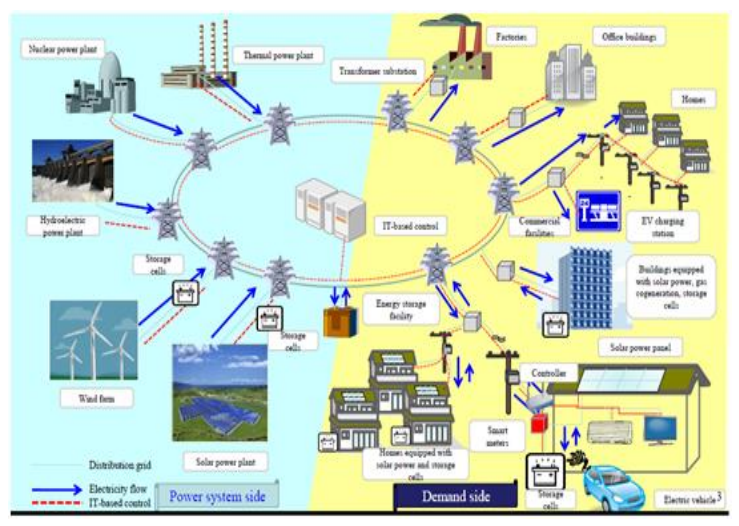

Gambar 1 Sistem Smart grid.

Sumber : Muqorobin A Dkk, 2011.

Metode pengaturan didapatkan berdasarkan data yang terkumpul pada ITbased control. Sensor dalam jumlah besar yang digunakan akan terus memantau (real time) data konsumsi energi, data cuaca, kondis peralatan, dan status operasi. Data dikirim melalui infrastruktur komunikasi dua arah dari berbagai titik pemantauan pada smart grid menuju pusat kontrol. Data tersebut kemudian digunakan untuk memprediksikan apa yang akan terjadi serta untuk mendapatkan strategi kontrol yang optimal pada sistem. Secara garis besar smart grid memiliki empat bagian besar, yaitu bagian sistem tenaga, bagian kontrol, bagian komunikasi, dan bagian aplikasi. 


\subsection{Keuntungan Penerapan Sistem Smart grid.}

Penerapan sistem smart grid memberikan keuntungan-keuntungan bagi penggunanya, diantaranya sebagai berikut:

1. Self healing: Istilah self healing mengacu pada kemampuan smart grid untuk mengantisipasi, mendeteksi dan merespon terhadap masalah atau gangguan yang terjadi pada sistem. Menggunakan informasi yang dikirim secara realtime oleh sensor-sensor yang dipasang di seluruh sistem, smart grid dapat secara cepat bereaksi untuk mengatasi gangguan yang terjadi. Contohnya bila terjadi gangguan pada suatu sistem distribusi di suatu daerah yang mengakibatkan padamnya listrik di daerah tersebut, maka alat-alat proteksi yang dipasang di daerah tersebut akan mengisolasi gangguan sumber gangguan sehingga tidak mengakibatkan pemadaman yang lebih luas ke daerah yang jauh dari sumber gangguan.

2. Consumer participation : konsumen lebih tahu bagaimana cara berhemat listrik dengan pertimbangan informasi real time tentang keadaan sistem. Lebih jauh lagi, bila pelanggan memiliki panel surya atau turbin angin, mereka dapat menggunakan sendiri, menyimpan, atau menjual listrik yang dihasilkan kepada produsen. Hal ini dimungkinkan karena tiap-tiap rumah sudah terkoneksi ke dalam sistem secara dua arah, sehingga listrik tidak hanya mengalir dari sistem ke rumah, tapi juga dari rumah ke sistem.

3. High quality power : konsep sistem yang lebih stabil dimana losses atau rugi-rugi bisa lebih dihindari (Pambudi C S, 2013)

\subsection{Tantangan Penerapan Sistem Smart grid.}

Dalam penerapan sistem smart grid, banyak tantangan yang dihadapi. Sebagai contoh tantangan penerapan sistem smart grid yaitu di perusahaan Austin Energi dan Xcel Energy serta kelompok industri terkemuka seperti GridWise Alliance mendapatkan masalah terkait dengan standardisasi. Pada dasarnya smart grid tidak dapat dikatakan "smart" jika sistem dan teknologi secara independen dikembangkan sepihak oleh tiap perusahaan karena dapat menghasilkan sistem yang tidak kompatibel dan tidak didukung oleh sebuah kerangka kerja yang standar untuk komunikasi antara perangkat. Jika standar belum ditetapkan, tidak ada jaminan bagi teknologi smart grid agar dapat plug and play serta solusi masalah yang kurang baik sepanjang jaringan. Perusahaan dan vendor juga tidak akan mau berinvestasi untuk mengembangkan peralatan yang mahal dan tidak kompatibel pada sistem. Pembuatan aturan untuk standarisasi memiliki ruang lingkup yang sangat luas dan kompleks karena bergantung terhadap seperti apa visi smart grid sebenarnya. Karena inilah stadarisasi menjadi tantangan yang sangat besar. Nilai dari smart grid yang sebenarnya secara langsung bergantung pada fase perkembangan dan implementasi teknologi di lapangan yang meliputi sekuritas, intelejensi, dan interkoneksi penuh pada sistem grid. Hingga saat ini terdapat banyak standar yang diadopsi oleh perusahaan -perusahaan yang terkait smart grid. Akibatnya, isu standardisasi adalah tantangan yang paling dibahas pada smart grid saat ini.

\subsection{Perkembangan Smart grid di Indonesia.}

$\mathrm{Di}$ Indonesia saat ini sudah ada demo plant (pilot projek) smart microgrid Sumba berada di Desa Billa Cenge, Sumba Barat Daya. Smart grid yang dibuat sebagai pilot percontohan mengintegrasikan energi surya, mikro hidro, dan pembangkit diesel dengan tujuan untuk mengurangi penggunaan bahan bakar diesel yang banyak digunakan di daerah terpencil seperti di Pulau Sumba. Implementasi smart grid akan memberi keuntungan yang lebih besar karena jumlah pembangkit terbarukan dan unit penyimpan yang terdistribusi dan terintegrasi meningkat, efisiensi meningkat, biaya operasional menurun, keandalan meningkat dan emisi CO2 menurun.

Demo plant smart microgrid di Sumba Barat Daya ini terdapat Pembangkit Listrik Tenaga Surya (PLTS) di Desa Bila Cenge, Kecamatan Kodi Utara, Kabupaten Sumba Barat Daya, Nusa Tenggara Timur (NTT) merupakan yang terbesar di Indonesia. Berbeda dengan PLTS lainnya di tanah air, kapasitas daya total PLTS di Bila Cenge ini mencapai $500 \mathrm{KWp}$ dan mampu mengalirkan listrik untuk sebanyak 1.000 rumah dengan daya 500 Watt per rumah.

Secara garis besar, pusat kontrol (master controller) berlokasi di Billa Cenge, mengintegrasikan pembangkit PV berkapasitas $500 \mathrm{kWp}$ ke jaringan listrik 20kV milik PLN yang saat ini didukung oleh dua pusat pembangkit listrik tenaga diesel di kota Waikabubak (7 unit kap 4,5 MW) yang berjarak $60 \mathrm{~km}$ dari pusat kontrol smart micro grid dan di kota Tambolaka (4 unit kap 2,1 MW) berjarak $20 \mathrm{~km}$ serta pembangkit Micro Hidro Lokomboro (5 unit) yang berjarak $50 \mathrm{~km}$. 
Pengendalian smart grid Sumba dilakukan oleh master controller yang terpasang di Bila Cenge bersama Remote Terminal Unit (RTU) yang terpasang di setiap sistem pembangkit tersebut (Suara Manado, 2012).

Komunikasi data antara master controller dengan seluruh slave controller (RTU) dilakukan melalui bantuan VSAT (satelit) berhubung kontur wilayah Sumba yang berbukit-bukit. Setiap RTU dilengkapi dengan sensor yang digunakan untuk membaca parameter kelistrikan di setiap pembangkit seperti tegangan, arus serta frekuensi, kemudian RTU mengirimkan data tersebut ke master controller untuk diolah dan dianalisis sebagai dasar dari pengambilan keputusan. Namun pada kondisi emergency, RTU akan mengambil alih fungsi kendali setiap pembangkit dan fasilitas PLTS ini juga bisa dikontrol dari Jakarta.

Di masa depan, masyarakat atau swasta bukan saja membeli listrik, tapi juga bisa menghasilkan dan menjual listriknya ke PLN. Teknologi smart grid ini juga mampu mengaturnya. Ini solusi tepat pada era semakin meningkatnya pemanfaatan berbagai energi terbarukan. Untuk mengantisipasi fluktuasi keluaran daya pembangkit PV dan efiesiensi energi digunakan perangkat smart storage berkapasitas $500 \mathrm{kWh} /$ hari. Sebagai gambaran, ketika PLTS tidak dapat mensuplay listrik pada malam hari, maka listrik di suplay dari baterai yang telah diisi oleh kelebihan listrik pada siang hari dari pembangkit listrik mikro hidro.

\section{METODE PENELITIAN}

\subsection{Kerangka Pikir Penelitian.}

Penelitian ketersediaan standar dalam mendukung penerapan sistem smart grid di indonesia ini mengikuti kerangka pikir sesuai dengan Gambar 2, sebagai berikut:

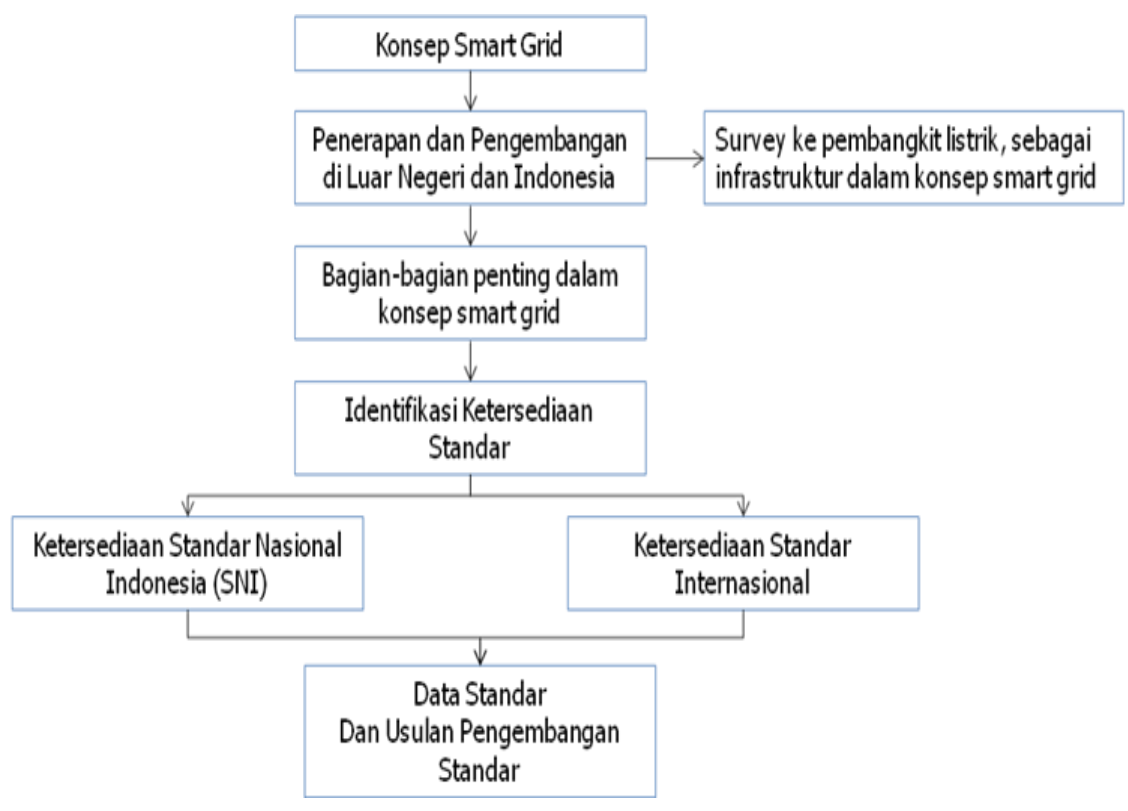

Gambar 2 Kerangka pikir penelitian.

\subsection{Metode Pengumpulan dan Analisa Data}

Pelaksaaan penelitian ini menggunakan metode survei langsung ke objek penelitian dilanjutkan dengan desk study. Metode pengumpulan data penelitian meliputi 3 bagian data yaitu data ketersediaan Standar Nasional Indonesia (SNI), data ketersediaan Standar Internasional yang meliputi standar dari IEC, IEEE, ISO, ANSI, DIN, KATS, BSMI, SAC dan JIS. Sedangkan data komponen utama dan pendukung penerapan sistem smart grid di ambil dari pilot projek sistem smart grid di Sumba Barat Daya (Pulau Sumba).
Penelitian ini merupakan studi kasus, dengan lokasi survey utama di Sumba Barat Daya Sedangkan analisa data menggunakan metode analisa data deskriptif kualitatif. Analisis deskriptif kualitatif merupakan suatu teknik yang menggambarkan dan menginterpretasikan arti dari data-data yang telah terkumpul dengan memberikan perhatian dan merekam sebanyak mungkin aspek situasi yang diteliti pada saat itu, sehingga memperoleh gambaran secara umum dan menyeluruh tentang keadaan sebenarnya. Menurut M. Nazir (1988) bahwa tujuan 
deskriptif ini adalah untuk membuat deskripsi, gambaran atau lukisan secara sistematis, faktual dan akurat mengenai fakta-fakta, sifatsifat serta hubungan antar fenomena yang diselidiki. Pembahasan dan analisa data kajian ini dilakukan untuk tujuan untuk mengetahui ketersediaan standar dalam penerapan smart grid di Indonesia.

\subsection{Batasan Penelitian.}

Batasan dan ruang lingkup penelitian ini yaitu objek penelitian adalah pilot projek sistem smart grid di Sumba Barat Daya. Data primer dan sekunder terkait dengan peralatan produksi dan distribusi sumber energi listrik smart grid dan yang diperoleh dari bulan Januari sampai dengan bulan November 2013. Sistem smart grid yang dibahas dalam kajian ini adalah sistem smart grid hanya sampai dengan sistem pengaturan penyaluran beban/distribusi daya listrik.

\section{PEMBAHASAN DAN ANALISA}

Komponen sistem smart grid menjadi sangat penting untuk menunjang pelaksanaan sistem tersebut. Tanpa adanya peralatan dan komponen pendukung yang baik dan saling support maka pelaksanaan sistem ini akan menemui banyak kendala. Komponen sistem smart grid yang dibahas pada penelitian ini adalah komponen sistem smart grid yang dgunakan di Pulau Sumba yang merupakan pilot projek sistem smart grid. Secara garis besar komponen utama sistem smart grid dibagi menjadi 6 bagian, sebagai berikut:

\subsection{Sistem Photovoltaics (PV).}

Teknologi PV dapat mengkonversi langsung cahaya matahari menjadi listrik melalui perangkat semikonduktor yang disebut sel surya. Teknologi PV dimanfaatkan untuk pembangkit listrik tenaga surya (PLTS) berupa sistem terpusat (centralized), sistem tersebar (stand alone) dan sistem hibrida (hybrid system). Centralized PV system adalah pembangkit listrik tenaga surya (PLTS) yang mensuplai listrik secara terpusat untuk berbagai lokasi/ beban yang bersifat on grid maupun off grid. Sistem stand alone hanya mensuplai listrik khusus untuk kebutuhan beban yang tersebar di masing-masing lokasi dan bersifat off grid. Komponen dan ketersediaan standar sistem photovoltaic dapat dilsajikan pada Tabel 1 .

Tabel 1 Komponen dan ketersediaan standar pada sistem photovoltaic.

\begin{tabular}{|c|c|c|c|}
\hline No & $\begin{array}{c}\text { Peralatan } \\
\text { (Komponen Utama) }\end{array}$ & $\begin{array}{c}\text { Peralatan } \\
\text { (Komponen Pendukung) }\end{array}$ & Ketersediaan Standar \\
\hline 1 & PV module & Bypass diode & \multirow{9}{*}{$\begin{array}{l}\text { Diperoleh } 18 \text { SNI dan } 114 \\
\text { standar internasional dan luar } \\
\text { negeri yang meliputi IEC, IEEE, } \\
\text { DIN, KATS, BSMI, SAC dan JIS } \\
\text { (daftar lengkap terlampir). }\end{array}$} \\
\hline 2 & Combiner box & $\begin{array}{l}\text { Fuse } 1000 \mathrm{~V}, 2 \mathrm{~A} \\
\text { Blocking diode } 1000 \mathrm{~V}, 6 \mathrm{~A} \\
\text { MCB } 1000 \mathrm{~V}, 20 \mathrm{~A} \\
\text { Arrester }\end{array}$ & \\
\hline & & $\begin{array}{l}\text { Kabel input NYAF } 1 \times 2,5 \mathrm{~mm}^{2} \text {, output } \\
\text { NYAF } 1 \times 35 \mathrm{~mm}^{2}\end{array}$ & \\
\hline 3 & Collection box & $\begin{array}{l}\text { Terminal dan Busbar (Dcbus } 300 \mathrm{~A} \text { ) } \\
\text { Kabel input NYAF } 1 \times 35 \mathrm{~mm} 2 \text {, output } \\
\text { NYAF } 1 \text { × } 70 \mathrm{~mm} 2\end{array}$ & \\
\hline \multirow[t]{3}{*}{4} & Inverter Grid Connected & Trafo isolasi & \\
\hline & & Display / HMI & \\
\hline & & $\begin{array}{l}\text { Proteksi over/low voltage } \\
\text { Anti-islanding } \\
\text { Over heating protection } \\
\text { Lighting protection } \\
\text { Kabel input NYAF } 1 \text { × } 70 \mathrm{~mm} 2 \text {, output } \\
\text { NYY } 4 \text { × } 95 \mathrm{~mm} 2 \text {. }\end{array}$ & \\
\hline 5 & Support PV module & & \\
\hline 6 & Sistem Grounding & & \\
\hline
\end{tabular}

Sumber : data diolah, 2013.

\subsection{Sistem Baterai.}

Baterai adalah obyek kimia penyimpan arus listrik. Baterai merupakan suatu alat penting yang sangat membantu di dalam sistem smart grid. Dalam hal ini fungsi baterai yaitu sebagai alat penyimpan sumber daya yang telah diproduksi baik dari energi listrik dengan bahan baku/bakar minyak solar (BBM); sumber energi matahari, sumber energi angin, sumber energi batubara, sumber energi air, 
sum, berenergi angin dan lain-lain sumber energi yang dijadikan sebagai sumber pembangkit energi untuk kepentingan pembangkitan energi listrik. Dalam sistem solar cell, energi listrik dalam baterai digunakan pada malam hari dan hari dimana kondisi minim sinar matahari (mendung). Karena intensitas sinar matahari bervariasi sepanjang hari, baterai memberikan energi yang konstan.

Baterai tidak seratus persen efisien, beberapa energi hilang seperti panas dari reaksi kimia, selama charging dan discharging. Charging adalah saat energi listrik diberikan kepada baterai, discharging adalah pada saat energi listrik diambil dari baterai. Satu cycle adalah charging dan discharging. Dalam sistem solar cell, satu hari dapat merupakan contoh satu cycle baterai (sepanjang hari charging, malam digunakan/ discharging).

Spesifikasi teknis baterai yang digunakan pada sistem smart grid di Sumba Barat Daya adalah baterai Vanadium Redox dengan kapasitas energi $500 \mathrm{kWh}$ dan kapasitas daya 400 kW. Sedangkan komponen dan ketersediaan standar sistem baterai disajikan pada Tabel 2 .

Tabel 2 Komponen dan ketersediaan standar pada sistem baterai.

\begin{tabular}{|c|c|c|c|}
\hline No & $\begin{array}{c}\text { Peralatan } \\
\text { (Komponen Utama ) }\end{array}$ & $\begin{array}{c}\text { Peralatan } \\
\text { (Komponen Pendukung) }\end{array}$ & Ketersediaan Standar \\
\hline 1 & Bateray & $\begin{array}{l}\text { Tank module } \\
\text { Stack module } \\
\text { Pompa } \\
\text { Panel }\end{array}$ & \multirow[t]{6}{*}{$\begin{array}{l}\text { Diperoleh } 7 \text { SNI dan } 28 \text { standar } \\
\text { internasional dan luar negeri yang meliputi } \\
\text { IEC, IEEE, DIN dan JIS (daftar lengkap } \\
\text { terlampir). }\end{array}$} \\
\hline 2 & $\begin{array}{l}\text { SCADA / BCR (Bateray } \\
\text { Charge Regulator) }\end{array}$ & & \\
\hline 3 & $\begin{array}{l}\text { Power Converter System } \\
\text { (PCS) }\end{array}$ & & \\
\hline \multirow[t]{3}{*}{4} & Bidirectional inverter & Trafo isolasi & \\
\hline & & $\begin{array}{l}\text { Display / HMI } \\
\text { Proteksi over/low voltage } \\
\text { Anti-islanding } \\
\text { Over heating protection } \\
\text { Lighting protection }\end{array}$ & \\
\hline & & $\begin{array}{l}\text { Kabel input NYAF } 1 \times 70 \mathrm{~mm} 2 \\
\text { output NYY } 4 \text { × } 95 \mathrm{~mm} 2\end{array}$ & \\
\hline
\end{tabular}

Sumber : data diolah, 2013.

\subsection{Sistem Kontrol dan Energy} Management System (EMS).

Sistem kontrol (control system) adalah proses pengaturan atau pengendalian terhadap satu atau beberapa besaran (variabel atau parameter) sehingga berada pada suatu harga atau range tertentu. Sedangkan Energy Management System (EMS) merupakan inovasi perpaduan antara hardware dan software yang dapat menghemat sampai dengan $30 \%$ dari pengguna energi listrik yang digunakan konsumen. EMS bekerja sebagai dinamis kontrol di dalam ruang lingkup aplikasi dan kondisi yang luas, alat ini diterapkan secara custom made order yang disesuaikan dengan masing-masing kasus yang dihadapi konsumen. EMS dapat mengatur jumlah daya yang dibutuhkan secara tepat guna dalam waktu yang sangat singkat.
Secara garis besar, pusat kontrol (master controller) pilot projek sistem smart grid di Sumba Barat Daya berlokasi di Billa Cenge, mengintegrasikan pembangkit PV berkapasitas $500 \mathrm{kWp}$ ke jaringan listrik 20kV milik PLN yang saat ini didukung oleh dua pusat pembangkit listrik tenaga diesel di kota Waikabubak (7 unit kap 4,5 MW) yang berjarak $60 \mathrm{~km}$ dari pusat kontrol smart micro grid dan di kota Tambolaka (4 unit kap 2,1 MW) berjarak $20 \mathrm{~km}$ serta pembangkit Micro Hidro Lokomboro (5 unit) yang berjarak $50 \mathrm{~km}$. Pengendalian smart grid Sumba dilakukan oleh master controller yang terpasang di Bila Cenge bersama Remote Terminal Unit (RTU) yang terpasang di setiap sistem pembangkit tersebut (Suara Manado, 2012). Secara garis besar komponen dan ketersdiaan standar sistem kontrol dan Energy Management System (EMS) disajikan pada Tabel 3. 
Tabel 3 Komponen dan ketersediaan stadar pada sistem kontrol dan EMS.

\begin{tabular}{|c|c|c|c|}
\hline No & $\begin{array}{c}\text { Peralatan } \\
\text { (Komponen Utama ) }\end{array}$ & $\begin{array}{c}\text { Peralatan } \\
\text { (Komponen Pendukung) }\end{array}$ & Ketersediaan Standar \\
\hline 1 & Master Control Station & $\begin{array}{l}\text { Master Controller } \\
\text { Engineering Workstation } \\
\text { Operator Workstation } \\
\text { HMI software } \\
\text { SCADA } \\
\text { UPS System } \\
\text { Hub Switch } \\
\text { Antena / modem }\end{array}$ & $\begin{array}{l}\text { Diperoleh } 7 \\
\text { internasional dan lan } 93 \text { standar } \\
\text { meliputi IEC, IEEE, DIN, KATS, JIS, } \\
\text { ANSI dan ISO (daftar lengkap } \\
\text { terlampir). }\end{array}$ \\
\hline \multirow[t]{2}{*}{2} & $\begin{array}{lc}\text { Slave Controller } \\
\text { Photovoltaic Substation }\end{array}$ & $\begin{array}{l}\text { Alat ukur / sensor (I VA , I Var ,V \& f) } \\
\text { Panel RTU (Remote Terminal Unit) } \\
\text { Relay proteksi } \\
\text { SCADA }\end{array}$ & \\
\hline & & Antena / modem & \\
\hline \multirow[t]{2}{*}{3} & $\begin{array}{l}\text { Slave Controller } \\
\text { Storage Substation }\end{array}$ & $\begin{array}{l}\text { Alat ukur / sensor (I VA , I Var ,V \& f) } \\
\text { Panel RTU (Remote Terminal Unit) } \\
\text { Relay proteksi }\end{array}$ & \\
\hline & & SCADA & \\
\hline 4 & $\begin{array}{l}\text { Slave Controller Genset } \\
\text { Substation }\end{array}$ & $\begin{array}{l}\text { Alat ukur / sensor } \\
\text { (I VA, I Var ,V \& f) } \\
\text { Panel RTU (Remote Terminal Unit) } \\
\text { Alarm } \\
\text { SCADA } \\
\text { Relay } \\
\text { Antena/Modem }\end{array}$ & \\
\hline 5 & $\begin{array}{l}\text { Slave Controller } \\
\text { Microhydro Substation }\end{array}$ & $\begin{array}{l}\text { Alat ukur / sensor (I VA , I Var ,V \& f) } \\
\text { Panel RTU (Remote Terminal Unit) } \\
\text { Alarm } \\
\text { SCADA } \\
\text { Antena/modem }\end{array}$ & \\
\hline \multirow[t]{2}{*}{6} & $\begin{array}{l}\text { Slave Controller Load ( } \\
\text { beban } 1 \text { ) }\end{array}$ & $\begin{array}{l}\text { Motorized LBS } \\
\text { Alat ukur / sensor (I VA, I Var ,V \& f) } \\
\text { Panel RTU (Remote Terminal Unit) } \\
\text { Alarm } \\
\text { SCADA }\end{array}$ & \\
\hline & & Antena/modem & \\
\hline
\end{tabular}

Sumber : data diolah, 2013.

\subsection{Sistem Komunikasi.}

Jaringan komputer dan komunikasi data memainkan peranan penting dalam sistem smart grid. Sistem komunikasi yang digunakan harus mempunyai kecepatan yang memadai, mempunyai dua arah komunikasi, dan terintegrasi secara penuh sehingga menjadikan smart grid begitu dinamis dan interaktif untuk pertukaran data dan daya secara real time.

Dengan pengukuran real time dan berkecepatan tinggi, proteksi dan aksi kontrol yang sesuai dapat dilakukan untuk menjamin keandalan sistem saat terjadi gangguan. Penyaluran dan akuisisi informasi secara luas, real time, dan cepat merupakan kunci pengontrolan dan optimasi operasi sistem tenaga pada wilayah yang luas. Untuk mendukung kebutuhan komunikasi data tersebut, teknologi dan arsitektur komunikasi masa depan harus dapat memberikan informasi data real time pada saat sistem membutuhkannya. Selain itu, jaringan di masa depan membutuhkan protokol dan standar, sehingga memudahkan dalam implementasinya.

Pilot projek sistem smart grid di Sumba Barat Daya mempunyai sistem komunikasi, dimana data antara master controller dengan seluruh slave controller (RTU) dilakukan melalui bantuan VSAT (satelit) berhubung kontur wilayah Sumba yang berbukit-bukit. Setiap RTU dilengkapi dengan sensor yang digunakan untuk membaca parameter kelistrikan di setiap pembangkit seperti tegangan, arus serta frekuensi, kemudian RTU mengirimkan data tersebut ke master 
controller untuk diolah dan dianalisis sebagai dasar dari pengambilan keputusan. Secara garis besar, komponen dan ketersediaan standar sistem komuniksi smart grid dapat dilihat pada Tabel 4.

Tabel 4 Komponen dan ketersediaan standar pada sistem komunikasi.

\begin{tabular}{llll}
\hline No & \multicolumn{1}{c}{$\begin{array}{c}\text { Peralatan } \\
\text { (Komponen Utama) }\end{array}$} & $\begin{array}{c}\text { Peralatan } \\
\text { (Komponen Pendukung) }\end{array}$ & \multicolumn{1}{c}{ Ketersediaan Standar } \\
\hline 1 & Telecomunication option : & & $\begin{array}{l}\text { Diperoleh 15 standar internasional dan luar } \\
\text { negeri yang meliputi IEC, DIN dan SAC } \\
\text { (daftar lengkap terlampir). }\end{array}$ \\
& VSAT & Antena & \\
& & Modem & \\
GPRS & Modem & \\
Radio link & Antena & \\
& Tower & \\
& Modem & \\
\end{tabular}

Sumber : data diolah, 2013.

\subsection{Sistem Genset (Biodisel).}

Genset atau kepanjangan dari generator set adalah sebuah perangkat yang berfungsi menghasilkan daya listrik. Disebut sebagai generator set dengan pengertian adalah satu set peralatan gabungan dari dua perangkat berbeda yaitu engine dan generator atau alternator. Alat ini bekerja berdasarkan prinsip percobaan dari Faraday (seorang ilmuwan), yang mana terdapat perputaran magnet atau kumparan. Pada saat magnet dalam kumparan digerakkan akan terjadi perubahan pada fluks gaya magnet atau perubahan pada arah penyebaran medan magnet. Hal ini mengakibatkan terjadinya beda potensial antar ujung-ujung kumparan sehingga menghasilkan energi listrik (Hamam, 2013).

Spesifikasi teknis sistem genset (biodiesel) pada pilot projek sistem smart grid di Sumba Barat Daya yaitu kapasitas 2 x 135 kVA dengan dilengkapi Electric Governor, remote start dari Smart MicroGrid Controller dan synchronizer. Secara garis besar, komponen dan ketersediaan standar sistem genset (Biodisel) disajikan pada Tabel 5.

Tabel 5 Komponen dan ketersediaan standar sistem genset (biodisel).

\begin{tabular}{|c|c|c|c|}
\hline No & $\begin{array}{c}\text { Peralatan } \\
\text { (Komponen Utama ) }\end{array}$ & $\begin{array}{c}\text { Peralatan } \\
\text { (Komponen Pendukung) }\end{array}$ & Ketersediaan Standar \\
\hline 1 & Genset & $\begin{array}{l}\text { Tangki bahan bakar } \\
\text { Remote start-stop }\end{array}$ & $\begin{array}{l}\text { Diperoleh } 7 \text { SNI dan } 19 \text { standar internasional } \\
\text { dan luar negeri yang meliputi IEC, DIN dan }\end{array}$ \\
\hline 2 & Panel Schyncronizer & -1 & SAC (daftar lengkap terlampir). \\
\hline
\end{tabular}

Sumber : data diolah, 2013.

\subsection{Sistem Micro Hydro.}

Mikrohidro atau yang dimaksud dengan Pembangkit Listrik Tenaga Mikrohidro (PLTMH), adalah suatu pembangkit listrik skala kecil yang menggunakan tenaga air sebagai tenaga penggeraknya seperti saluran irigasi, sungai atau air terjun alam dengan cara memanfaatkan tinggi terjunan (head) dan jumlah debit air. Mikrohidro merupakan sebuah istilah yang terdiri dari kata mikro yang berarti kecil dan hidro yang berarti air. Secara teknis, mikrohidro memiliki tiga komponen utama yaitu air (sebagai sumber energi), turbin dan generator. Mikrohidro mendapatkan energi dari aliran air yang memiliki perbedaan ketinggian tertentu. Pada dasarnya, mikrohidro memanfaatkan energi potensial jatuhan air (head). Semakin tinggi jatuhan air maka semakin besar energi potensial air yang dapat diubah menjadi energi listrik. Air dialirkan melalui sebuah pipa pesat kedalam rumah pembangkit yang pada umumnya dibagun di bagian tepi sungai untuk menggerakkan turbin atau kincir air mikrohidro. Energi mekanik yang berasal dari putaran poros turbin akan diubah menjadi energi listrik oleh sebuah generator. Perbedaan antara Pembangkit Listrik Tenaga Air (PLTA) dengan mikrohidro terutama pada besarnya tenaga listrik yang dihasilkan, PLTA dibawah ukuran 200 KW digolongkan sebagai mikrohidro. Dengan demikian, sistem pembangkit mikrohidro cocok untuk menjangkau ketersediaan jaringan energi listrik di daerah-daerah terpencil dan pedesaan (Wikipedia, 2013).

Spesifikasi Teknis sistem mikro hydro smart grid di Sumba Barat daya adalah dengan kapasitas 1 x $800 \mathrm{~kW}$, kapasitas : 2 x 500 kW dan kapasitas : 2 x 250 kW. Secara garis besar komponen dan ketersediaan standar sistem mikro hydro disajikan pada Tabel 6. 
Tabel 6 Komponen utama dan pendukung Micro Hydro.

\begin{tabular}{llcl}
\hline No & $\begin{array}{c}\text { Peralatan } \\
\text { (Komponen Utama) }\end{array}$ & $\begin{array}{c}\text { Peralatan } \\
\text { (Komponen Pendukung) }\end{array}$ & Ketersediaan Standar \\
\hline Turbin air & - & $\begin{array}{l}\text { Diperoleh } 9 \text { SNI dan 36 standar internasional } \\
\text { dan luar negeri dari IEC dan IEEE (daftar } \\
\text { lengkap terlampir). }\end{array}$ \\
\hline
\end{tabular}

Sumber : data diolah, 2013.

\section{KESIMPULAN}

Kesimpulan yang didapatkan dari penelitian ini yaitu sistem smart grid di pilot projek Sumba Barat Daya mempunyai 6 komponen utama yaitu sistem photovoltaic, sistem baterai, sistem kontrol dan Energy Management Systems (EMS), sistem komunikasi, sistem genset (biodisel) dan sistem micro hydro. Ketersediaan standar sistem photovoltaic yaitu $18 \mathrm{SNI}$ dan 114 standar internasional dan standarmanca negara (IEC, IEEE, DIN, KATS, BSMI, SAC dan JIS). Ketersediaan standar sistem baterai yaitu 7 SNI dan 28 standar internasional dan mancanegara (IEC, IEEE, DIN dan JIS). Ketersediaan standar sistem kontrol dan Energy Management Systems (EMS) yaitu $7 \mathrm{SNI}$ dan 93 standar internasional dan mancanegara (IEC, IEEE, DIN, KATS, JIS, ANSI dan ISO). Ketersediaan standar sistem komunikasi yaitu 15 standar internasional dan mancanegara (IEC, DIN dan SAC). Ketersediaan standar sistem genset (biodisel) yaitu $7 \mathrm{SNI}$ dan 19 standar internasional dan mancanegara (IEC, DIN dan SAC). Sedangkan ketersediaan standar untuk sistem micro hydro yaitu $9 \mathrm{SNI}$ dan 36 standar internasional dan manca negara (IEC dan IEEE).

Rekomendasi yang dapat disampaikan dari hasil kajian ini yaitu memperhatikan sumbersumber energi yang ada dan kondisi wilayah Indonesia yang terdiri dari sekitar 17.000 pulaupulau besar dan kecil, maka sistem smart grid ini sangat cocok dikembangkan di Indonesia. Mengingat pentingnya sistem smart grid untuk masa depan elektrifikasi di Indonesia, diusulkan kepada pemerintah melalui Badan Standardisasi Nasional (BSN), dapat mendukung dengan membentuk panitia teknis atau sub panitia teknis perumusan SNI khusus untuk "sistem smart grid". Pemerintah melalui Badan Standardisasi Nasional (BSN) dan instansi teknis terkait dapat mengembangkan SNI terkait sistem smart grid dengan mengacu pada standar-standar internasional hasil identifikasi dari penelitian ini.

\section{DAFTAR PUSTAKA}

Alhanif, E. (2007). Langkah Strategis Mengatasi Krisis Energi Listrik. Diakses 1 Desember 2013

dari http://inparametric.com/bhinablog/downloa d/factor_analysis_patria.pdf.

American National Standard Institute (ANSI). (2013). Daftar Standar ANSI Sistem Smart grid. Diakses tanggal 1 April 2013 dari http://webstore.ansi.org/.

Aprilianto C. (2013). Mendorong Rasio Elektrifikasi demi Pemerataan Pembangunan. Diakses 1 November 2013 dari http://migasreview.com/mendorongrasio-elektrifikasi-demi-pemerataanpembangunan.html.

Bureau of Standards, Metrology and Inspection (BSMI). (2013). Daftar Standar DIN Sistem Smart grid. Diakses tanggal 1 April 2013 dari

http://www.cnsonline.com.tw/?node=searc h\&locale=en_US.

Deutsches Institut für Normung (DIN). (2013). Daftar Standar DIN Sistem Smart grid. Diakses tanggal 1 April 2013 dari http://www.din.de/cmd?level=tplhome\&contextid=din.

Epsdin. (2007). Langkah Strategis Mengatasi Krisis Energi Listrik. Diakses 1 Desember 2013 dari http://epsdin.wordpress.com/2007/06/23/la ngkah-strategis-mengatasi-krisis-energilistrik/.

Korean Agency for Technology and Standards (KATS). Daftar Standar KATS Sistem Smart grid. Diakses tanggal 1 April 2013 dari http://www.kats.go.kr/english/com/search_ ks.asp?OlapCode=ATSU27.

Institute of Electrical and Electronics Engineers (IEEE). (2013). Daftar Standar IEEE Sistem Smart grid. Diakses tanggal 1 April 2013 dari http://standards.ieee.org/.

International Electrotechnical Commission (IEC). (2010). IEC Smart grid Standardization Roadmap. Geneva - Switzerland. 
International Electrotechnical Commission (IEC). (2013). Daftar Standar IEC Sistem Smart grid. Diakses tanggal 1 April 2013 dari http://webstore.iec.ch/?ref=menu.

International Organization for Standardization. (2013). Daftar Standar ISO Sistem Smart grid. Diakses tanggal 1 April 2013 dari http://www.iso.org/iso/home/store/catalogu e_ics.htm.

Hamam. (2013). Prinsip kerja dan instalasi Genset. Diakses 1 November 2013 dari http://hamamww.ngeblog.ittelkom.ac.id/20 13/09/15/prinsip-kerja-dan-instalasigenset/.

Happy Yolanda, H. (2013) . Materi Presentasi Smart grid. Jakarta.

Japanese Industrial Standards (JIS). (2013). Daftar Standar JIS Sistem Smart grid. Diakses tanggal 1 April 2013 dari http://www.webstore.jsa.or.jp/webstore/JIS /SearchEn.jsp.

Kementerian Energi dan Sumber Daya Mineral. (2012). Rencana Umum Ketenagalistrikan Nasional 2012 - 2031. Jakarta.

Muqorobin, A Dkk. (2011). Smart grid Untuk Jaringan Listrik Masa Depan. Diakses 1 November 2013 dari http://kuliah-jugaibadah.blogspot.com/2011/10/smart-griduntuk-jaringan-listrik-masa.html.

Nazir, M. (1988). Metode Penelitian, Cetakan Ketiga. Penerbit Ghalia. Indonesia.

Pambudi, C S. (2013). Teknologi Jaringan Pintar (Smart grid). Diakses 1 November 2013 dari http://www.pantonashare.com/4380teknologi-jaringan-pintar-smart-grid.

Pusat Penelitian dan Pengembangan Teknologi Ketenagalistrikan dan Energi Baru Terbarukan (P3TKEBT - KESDM). (2012). Photovoltaik. Diakses 1 November 2013 dari

http://www.p3tkebt.esdm.go.id/index.php? option $=$ com_content\&view $=$ article $\& i d=377$ \&ltemid=486\&lang=en.

Rizqiawan, A. (2009). Smart grid: Menuju masa depan. Diakses 1 Desember 2013 dari http://konversi.wordpress.com/2009/11/08/ smart-grid-menuju-masa-depan/.

Standardization Administration of China (SAC). (2013). Daftar Standar SAC Sistem Smart grid. Diakses tanggal 1 April 2013 dari
http://www.sac.gov.cn/SACSearch/outlinet emplet/gjbzcx_en.jsp.

Sutrisno. (2013). Strategi Implementasi Smart grid di PT. PLN Batam Dengan Optimalisasi Aplikasi Teknologi Informasi dan Komunikasi (ICT). Batam.

Suara Manado. (2012). Smart Micro Grid : Saatnya Mencari Sumber Energi ke Pembangkit Energi Terbarukan. Diakses 1 November 2013 dari http://sg.suaramanado.com/berita/nasional /lain-lain/2012/06/4655/saatnya-mencarisumber-energi-ke-pembangkit-energiterbarukan.

Wikipedia. (2013). Mikrohidro. Diakses 1 November 2013 dari http://id.wikipedia.org/wiki/Mikrohidro. 
